\title{
Pengaruh Kualitas Pelayanan pada Kepuasan Peserta Pelatihan Dasar CPNS Kabupaten Tebo Provinsi Jambi
}

\author{
Musfarita Affiani \\ Widyaiswara BPSDM Provinsi Jambi
}

\begin{abstract}
Service quality including reliability, responsiveness, assurance, empathy and tangibility had a positive and significant effect on the satisfaction of training participants for candidates for civil servants. Efforts to improve service quality can be improved through service provision by referring to the dimensions of reliability, responsiveness, assurance, empathy and tangible, where assurance and empathy can be used as efforts to improve the quality of services that are more optimal. Finance Keywords: Quality Services, Training Participants Satisfaction.
\end{abstract}

Keywords: Service Quality, Satisfaction

\section{Pendahuluan}

Peningkatan kualitas sumber daya manusia khususnya pada sektor pemerintah daerah, merupakan suatu keharusan, karena pengembangan sumber daya manusia merupakan suatu solusi dari setiap masalah yang terjadi dalam organisasi pemerintahan. Pendidikan dan komunikasi yang baik antara para pelaku organisasi mempunyai pengaruh yang sangat penting terhadap kualitas pelayanan, dimana dapat terciptanya suatu kepuasan tersendiri dihati para konsumen. Melalui pendidikan individu dan masyarakat melakukan komunikasi antara satu sama yang lain sehingga kualitas pelayanan dapat terlihat dan dirasakan serta perilaku masing-masing. Begitu dengan instansi pemerintah, para pegawai maupun pimpinan berkomunikasi dan memberikan pelayanan yang benar-benar berkualitas untuk menjalin hubungan yang baik, untuk mencapai tujuan yang diharapkan. Dengan alasan ini instansi selalu berusaha memberikan pendidikan kepada setiap pegawai, baik pendidikan formal maupun pendidikan non formal.

Sumber daya manusia aparatur harus memiliki kompetensi dan profesionalitas yang tinggi karena merupakan aset bangsa dan Negara dalam melaksanakan pembangunan nasional di berbagai sektor. Untuk menciptakan sumber daya manusia aparatur yang memiliki kompentensi tersebut diperlukan peningkatan mutu profesionalisme dan pengembangan wawasan Pegawai Negeri Sipil. Pegawai Negeri Sipil (PNS) merupakan Aparatur Sipil Negara (ASN) yang memiliki peranan penting dalam mengelola kondisi Indonesia saat ini. Sejumlah kebijakan, keputusan-keputusan strategis, perencanaan pembangunan, dan pelayanan terhadap masyarakat ditetapkan dan dilakukan oleh PNS diberbagai bidang manapun sektor pembangunan. Untuk memainkan peranan tersebut, diperlukan sosok PNS yang profesional, yaitu PNS yang mampu memenuhi standar kompetensi dan melaksanakan tugas jabatannya secara efektif dan efisien.

Dalam peraturan pemerintah nomor 11 Tahun 2017 tentang manajemen PNS, disebut bahwa CPNS wajib menjalani masa percobaan selama 1 (satu) tahun. Masa percobaan tersebut merupakan masa prajabatan yang di lakukan melalui proses pendidikan dan pelatihan yang hanya di ikuti satu kali. Sesuai Peraturan Lembaga Administrasi Negara (LAN) RI Nomor 12 Tahun 2018 tentang Pedoman Penyelenggaraan Pelatihan Dasar Calon Pegawai Negeri Sipil Golongan III, maka Penyelenggaraan Pendidikan dan Pelatihan (DIKLAT) Prajabatan dilaksanakan dengan nomenklatur baru ialah Pelatihan Dasar Kader PNS, sebagai salah satu jenis Pelatihan yang strategis pasca UU ASN dalam rangka pembentukan kemampuan bersikap dan bertindak profesional yang berlandaskan pada nilai-nilai dasar yang meliputi : Akuntabilitas, Nasionalisme, Etika Publik, Komitmen Mutu dan Anti Korupsi, serta di sinkronkan dengan nilai-nilai dasar NKRI yang meliputi : Manajemen ASN, Whole of Government dan Pelayanan Publik. Kebutuhan pendidikan dan pelatihan yang berkualitas secara ideal memerlukan suatu sistem yang dinamis. Sistem diklat yang dinamis senantiasa membutuhkan data dan informasi akurat yang menggambarkan secara nyata dan objektif untuk dijadikan acuan dalam peningkatan mutu lulusan diklat. Diklat harus dipandang sebagai suatu sistem, dimana sistem dari pelatihan akan terdiri dari sub-sub sistem yang saling berinteraksi dalam mencapai tujuan pelatihan, sehingga pelatihan akan terlaksana secara sistematis, optimal dan terpadu. Namun, nampaknya banyak lembaga-lembaga diklat pemerintah yang belum melaksanakan diklat secara sistematis, optimal dan terpadu. Hal ini akan mengakibatkan tidak bertemunya dua titik, antara tujuan yang diharapkan dengan pengetahuan yang diperoleh selama pelatihan, sehingga menyebabkan ketidakseimbangan antara tuntutan tugas di organisasi dengan sumber daya manusia yang dimiliki.

Organisasi baik di sektor publik maupun swasta telah menginvestasikan anggaran yang besar untuk melaksanakan pelatihan, yang diharapkan dapat meningkatkan kinerja organisasi sebagai nilai balikan investasi (return on investment) dari program 
pengembangan pegawai ini. Dengan alokasi dana yang besar, maka masyarakat dan para pemangku kepentingan kediklatan mulai menyoroti efektifitas dan dampak penyelenggaraan diklat. Mengukur kualitas pelayanan jika hanya dilakukan oleh lembaga pemberi jasa itu sendiri cenderung menghasilkan ukuran yang bias, artinya lembaga pemberi jasa mengukur kualitas pelayanan berdasarkan selera pemberi jasa, bukan menurut selera pelanggan. Pelayanan jasa pendidikan dan pelatihan terbagi dalam dua jenis pelayanan yaitu, pelayanan pengajaran dan pelayanan administrasi. Salah satu instansi yang menyelenggarakan diklat adalah Badan Kepegawaian Sumber Daya Manusia Daerah Kabupaten Tebo. Badan ini ini mempunyaitugas dan fungsi sebagai pelayan dalam bidang administrasi kepegawaian serta instansi yang mempunyai bidang pengembangan sumber daya manusia aparatur khususnya dan masyarakat pada umumnya. Kualitas pelayanan penyelenggara Latsar menjadi faktor yang sangat penting karena kualitas pelayanan yang diberikan akan menentukan sejauh mana para peserta Latsar dapat mengikuti semua rangkaian kegiatan dalam Latsar. Pelayanan oleh penyelenggara Latsar itu nantinya akan menentukan berhasil atau tidaknya Latsar tersebut. Hal ini dimaklumi karenapada dasarnya Latsar serta pelayanan merupakan bagian yang diberikan merupakan satu keastuan proses yang akan menghasilkan suatu perubahan perilaku sasaran Latsar.bertanggung jawab terhadap pelayanan administrasi bagi peserta pelatihan. Apabila dilihat dari pendekatan system, maka proses pendidikan dan pelatihan terdiri dari input (sasaran diklat) dan output (perubahan perilaku) dan faktor yang mempengaruhi proses tersebut (software dan Hardware). Perangkat lunak meliputi kurikulum,organisasi diklat, peraturanperaturan, metode belajar mengajar, tenaga pengajar atau pelatih. Kualitas pelayanan yang diberikan kepada peserta latsar dalam penyelenggaraan latsar oleh BKPSDMD Kab. Tebo merupakan factor yang mempengaruhi pelaksanaan latsar serta menentukan tingkat kepuasan peserta latsar, namun kadang kala terdapat berbagai kekurangan. Hal ini dapat memungkinkan terjadinya ketidakpuasan peserta latsar terhadap kualitas pelayanan yang diberikan oleh penyelenggara diklat selama kegiatan latsar berlangsung. Sehingga ketidakpuasan tersebut menyebabkan peserta latsar tidak dapat mengikuti latsar dengan baik, maka tujuan latsarpun tidak dapat tercapai dengan baik. Untuk lebih jelas jumlah peserta Latsar Kabupaten Tebo Tahun 2019 dapat dilihat pada tabel berikut ini :

Tabel 1

Jumlah Peserta Latsar Kabupaten Tebo berdasarkan Golongan dan Jenis Kelamin

\begin{tabular}{|l|r|r|r|}
\hline \multirow{2}{*}{ Golongan } & \multicolumn{2}{|c|}{ Jenis Kelamin } & \multirow{2}{*}{ Jumlah } \\
\cline { 2 - 4 } & Laki-Laki & \multicolumn{1}{|c|}{ Perempuan } & \\
\hline III & 31 & 9 & 114 \\
\hline Total & 75 & 39 & 154 \\
\hline
\end{tabular}

Sumber : BKPSDMD Kabupaten Tebo

Tabel 2

Jumlah Peserta Latsar Kabupaten Tebo berdasarkan Formasi

\begin{tabular}{|l|r|r|r|r|}
\hline \multicolumn{1}{|c|}{ Golongan } & Guru & Teknis & Kesehatan & \multicolumn{2}{|c|}{ Jumlah } \\
\hline II & -- & 4 & 36 & 40 \\
\hline III & 81 & 16 & 17 & 114 \\
\hline Total & 81 & 20 & 53 & 154 \\
\hline
\end{tabular}

Sumber : BKPSDMD Kabupaten Tebo

Pelayanan administrasi yang diberikan oleh BKPSDMD Kabupaten Tebo akan diukur kualitasnya berdasarkan dimensi kualitas pelayanan yaitu reliabilitas (reliability), daya tanggap (responsiveness), jaminan (assurance), empati (empathy), dan bukti fisik (tangible) (Tjiptono, 2011). Kelima dimensi kualitas pelayanan tersebut lebih dikenal dengan SERVQUAL (Service Quality Model). Dengan adanya pelayanan kepada peserta Latsar, maka penting bagi Badan Kepegawaian Sumber Daya Manusia Kabupaten Tebo untuk mengetahui pengaruh langsung dan tidak langsung kualitas pelayanan Pelatihan Dasar terhadap kepuasan peserta. Keluhan-keluhan yang muncul saat pelaksanaan pelatihan dasar antara lain penyaluran air yang tidak lancar, fasilitas pendingin ruangan yang kurang berfungsi, panitia yang terkadang tidak ada saat proses belajar mengajar dan ruangan belajar yang kurang bersih.

\section{Literature Review}

Menurut Tse \& Wilton (Tjiptono \& Chandra, 2011) kepuasan adalah respon konsumen pada evaluasi persepsi terhadap perbedaan antara ekspektasi awal (atau standar kinerja tertentu) dan kinerja aktual produk sebagaimana dipersepsikan setelah konsumsi produk. Menurut Churcill \& Suprenant (Tjiptono \& Chandra, 
2011) kepuasan adalah hasil pembelian dan pemakaian yang didapatkan dari perbandingan yang dilakukan oleh pembeli atas reward dan biaya pembelian dengan konsekuensi yang diantisipasi. Menurut Kotler dan Keller (2003) kepuasan pelanggan adalah perasaan konsumen, baik itu berupa kesenangan atau kekecewaan yang timbul dari membandingkan penampilan sebuah produk dihubungkan dengan harapan konsumen atas produk tersebut. Ada beberapa metode yang bisa dipergunakan setiap perusahaan untuk mengukur dan memantau kepuasan pelanggannya dan pelanggan pesaing. Kotler, et al (Tjiptono \& Chandra, 2011) mengidentifikasi empat metode untuk mengukur kepuasan pelanggan, yaitu: 1) Sistem keluhan dan saran ; Setiap organisasi yang berorientasi pada pelanggan (customer oriented) perlu menyediakan kesempatan dan akses yang mudah dan nyaman bagi para pelanggannya guna menyampaikan saran, kritik, pendapat, dan keluhan, 2) Ghost Shopping ; Metode ini dilaksanakan dengan cara memperkerjakan beberapa orang (ghost shopper) untuk berperan atau berpura-pura sebagai pelanggan potensial produk perusahaan dan pesaing ; 3) Lost customer analysis ; Metode ini dilaksanakan dengan cara perusahaan menghubungi para pelanggan yang telah berhenti membeli atau yang telah pindah pemasok agar dapat memahami mengapa hal itu terjadi dan supaya dapat mengambil kebijakan perbaikan/penyempurnaan selanjuntya ; 4) Survei kepuasan pelanggan ; Penelitian mengenai kepuasan pelanggan dilakukan dengan menggunakan metode survei, baik melalui pos, telepon, email, websites, maupun wawancara langsung.

Jasa merupakan suatu hasil yang diciptakan melalui aktifitas dalam keterkaitan diantara pemasok dan pelanggan dan melalui aktifitas internal pemasok, untuk memenuhi kebutuhan pelanggan. Jasa sebagai setiap tindakan atau perbuatan yang dapat ditawarkan oleh suatu pihak kepada pihak lain yang pada dasarnya bersifat intangible (tidak berwujud fisik) dan tidak menghasilkan kepemilikan sesuatu. Produksi jasa bisa berhubungan dengan produk fisik maupun tidak. Jasa adalah semua tindakan atau kinerja yang dapat ditawarkan satu pihak kepada pihak lain yang pada intinya tidak berwujud dan tidak menghasilkan kepemilikan apapun (Kotler, 2009). Suatu produk / hasil dari jasa mungkin saja ataupun tidak mungkin berkaitan dengan produk fisik. Salah satu cara untuk membedakan sebuah perusahaan jasa adalah dengan memberikan jasa dengan kualitas yang lebih tinggi dari pesaingnya secara konsisten. Kuncinya adalah dengan memenuhi atau melebihi ekspektasi pelanggan. Ekspektasi pelanggan dibentuk oleh pengalaman masa lalunya, pembicaraan dari mulut ke mulut dan promosi yang dilakukan perusahaan. Dalam membeli jasa, pelanggan memilih penyedia jasa berdasarkan hal ini, dan setelah menerima jasa itu, mereka akan membandingkan jasa yang diterima dengan jasa yang diharapkan. Jika jasa yang diterima terletak di bawah jasa yang diharapkan, pelanggan tidak berminat lagi dengan penyedia jasa tersebut, sedangkan bila jasa yang diterima dirasakan memenuhi atau melebihi harapan maka pelanggan cenderung akan menggunakan kembali penyedia jasa tersebut. Implikasi dari karakteristik tersebut adalah sulit bagi pelanggan untuk mengevaluasi jasa pada tahap sebelum dikonsumsi, saat dikonsumsi dan setelah dikonsumsi untuk pembuatan keputusan pelanggan. Sebuah perusahaan jasa dapat memenangkan persaingan dengan menyampaikan secara konsisten layanan yang berkualitas lebih tinggi dibandingkan para pesaing dan yang lebih tinggi daripada harapan pelanggan.

Harapan-harapan itu dibentuk oleh pengalaman dimasa lalu, pembicaraan dari mulut ke mulut, dan iklan perusahaan jasa. Setelah menerima jasa itu, pelanggan membandingkan jasa yang dialami dengan jasa yang diharapkan. Jika jasa yang dialami berada dibawah jasa yang diharapkan, pelanggan tidak berminat lagi terhadap penyedia jasa itu. Jika jasa yang dialami memenuhi atau melebihi harapan, mereka akan menggunakan penyedia jasa itu lagi (Kotler, 2009). Kualitas pelayanan merupakan totalitas bentuk dari karakteristik barang atau jasa yang menunjukkan kemampuannya untuk memuaskan kebutuhan-kebutuhan pelanggan, baik yang Nampak jelas maupun yang tersembunyi (Kotler, 2009). Kualitas layanan jasa dapat diukur dengan melihat seberapa jauh efektifitas layanan jasa dapat mempertipis kesenjangan antara harapan dengan layanan jasa yang diberikan. Tjiptono \& Chandra (2011) menyatakan bahwa kualitas adalah kondisi dinamis yang berhubungan dengan produk, pelayanan, sumber daya manusia, proses dan lingkungan yang memenuhi atau melebihi harapan. Contoh, lokasi, biaya, status akreditasi, jumlah dan kualifikasi staf dan guru. Lebih lanjut Tjiptono, dkk (2011) menyatakan bahwa dalam rangka menciptakan kepuasan pelanggan, produk yang ditawarkan organisasi harus berkualitas. Karena kualitas memiliki sejumlah level: universal (sama dimanapun), kultural (tergantung sistem nilai budaya), sosial (dibentuk oleh kelas sosial ekonomi, kelompok etnis, keluarga, teman sepergaulan), dan personal (tergantung preferensi atau selera setiap individu). Kualitas layanan berkontribusi signifikan bagi pengembangan diferensiasi, positioning, dan strategi bersaing setiap organisasi pemasaran, baik perusahaan manufaktur maupun penyedia jasa. Lebih lanjut Tjiptono, dkk (2011) menyatakan bahwa kualitas layanan mencerminkan perbandingan antara tingkat layanan yang disampaikan dibandingkan ekspektasi pelanggan. Kualitas layanan diwujudkan melalui pemenuhan kebutuhan dan keinginan pelanggan serta ketepatan penyampaiannya dalam mengimbangi atau melampaui harapan pelanggan.

Parasuraman, dkk dalam Tjiptono \& Chandra (2011) membagi lima dimensi kualitas pelayanan jasa, yaitu: 
1. Reliabilitas (reliability), berkaitan dengan kemampuan perusahaan untuk memberikan layanan yang akurat sejak pertama kali tanpa membuat kesalahan apapun dan menyampaikan jasanya sesuai dengan waktu yang disepakati.

2. Daya tanggap (responsiveness), berkenaan dengan kesediaan dan kemampuan para karyawan untuk membantu para pelanggan dan merespon permintaan mereka, serta menginformasikan kapan jasa akan diberikan dan kemudian memberikan jasa secara cepat.

3. Jaminan (assurance), yakni perilaku para karyawan mampu menumbuhkan kepercayaan pelanggan terhadap perusahaan dan perusahaan bisa menciptakan rasa aman bagi para pelanggannya. Jaminan juga berarti bahwa para karyawan selalu bersikap sopan dan menguasai pengetahuan dan keterampilan yang dibutuhkan untuk menangani setiap pertanyaan atau masalah pelanggan.

4. Empati (emphaty), berarti bahwa perusahaan memahami masalah para pelanggannya dan bertindak demi kepentingan pelanggan, serta memberikan perhatian personal kepada para pelanggan dan memiliki jam operasi yang nyaman.

5. Bukti fisik (tangibles), berkenaan dengan daya tarik fasilitas fisik, perlengkapan, dan material yang digunakan perusahaan, serta penampilan karyawan.

Gummesson dalam Tjiptono \& Chandra (2011) mengidentifikasi empat sumber kualitas yang menentukan penilaian kualitas jasa, yaitu:

1. Design product, yang menjelaskan bahwa kualitas jasa ditentukan sejak pertama kali jasa dirancang untuk memenuhi kebutuhan pelanggan

2. Production quality, yang menjelaskan bahwa kualitas jasa ditentukan oleh kerja sama antara departemen produksi/operasi dan departemen pemasaran

3. Delivery quality, yang menjelaskan bahwa kualitas jasa dapat ditentukan oleh janji perusahaan kepada pelanggan

4. Relationship quality, yang menyatakan bahwa kualitas jasa ditentukan pula oleh relasi profesional dan sosial antara perusahaan dan stakeholder (pelanggan, pemasok, perantara, pemerintah, dan karyawan).

Ada beberapa faktor penyebab buruknya kualitas suatu jasa, menurut Tjiptono (2008):

1. Produksi dan konsumsi yang terjadi secara simultan

Salah satu karakteristik yang unik dari jasa adalah inseparability, artinya jada diproduksi dan dikonsumsi secara bersamaan. Hal ini kerap kali membutuhkan partisipasi pelanggan dalam proses penyampaian layanan. Beberapa kelemahan yang mungkin berdampak negatif terhadap persepsi kualitas meliputi:
- Tidak terampil dalam melayani pelanggan

- Cara berpakaian kurang sesuai dengan konteks

- Tutur kata karyawan kurang sopan atau bahkan menyebalkan

- Bau badan karyawan mengganngu kenyamanan pelanggan

- Karyawan selalu cemberut atau pasang tampang angker

2. Intensitas tenaga kerja yang tinggi

Keterlibatan karyawan secara intensif dalam penyampaian layanan dalam dapat dula menimbulkan masalah kualitas, yaitu berupa tingginya variabilitas layanan yang dihasilkan. Faktor-faktor yang mempengaruhinya antara lain upah yang rendah, pelatihan yang kurang memadai, tingkat perputaran karyawan terlalu tinggi, motivasi kerja karyawan rendah.

3. Dukungan terhadap pelanggan internal (pelanggan perantara) kurang memadai. Karyawan front-line merupakan ujung tombak sistem penyampaian layanan dan cerminan jasa yang dipersepsikan konsumen. Agar para karyawan front line mampu melayani pelanggan secara efektif, mereka membutuhkan dukungan dari fungsi-fungsi utama manajemen.

4. Gap/kesenjangan komunikasi

Komunikasi merupakan faktor esensial dalam menjalin kontak dan relasi dengan pelanggan. Bila terjadi gap komunikasi, maka bisa timbul penilaian atau persepsi negatif terhadap kualitas layanan. Gap-gap komunikasi dapat berupa:

a. Penyedia layanan memberikan janji yang berlebihan, sehingga tidak mampu memenuhinya

b. Penyedia layanan tidak bisa selalu menyediakan informasi terbaru kepada para pelanggan

c. Pesan komunikasi penyedia layanan tidak dipahami pelanggan

d. Penyedia layanan tidak memperhatikan atau tidak segera menindaklanjuti keluhan dan saran pelanggan.

5. Memperlakukan semua pelanggan dengan cara yang sama

Pelanggan merupakan individu unik dengan preferensi, perasaan dan emosi masing-masing, sehingga tidak semua pelanggan bersedia menerima layanan-layanan yang seragam (standardized service). Hal ini memuculkan tantangan-tantangan bagi penyedia layanan dalam hal kemampuan memahami kebutuhan spesifik pelanggan individulan dan memahami perasaan pelanggan terhadap penyedia layanan spesifik yang mereka terima. 
6. Perluasan atau pengembangan layanan secara berlebihan

Memperkenalkan layanan baru atau menyempurnakan layanan lama dapat meningkatkan peluang pertumbuhan bisnis dan menghindari terjadinya layanan-layanan yang buruk. Tetapi bila terlampau banyak layanan yang didapat belum tentu optimal bahkan mungkin saja timbul masalah-masalah standar kualitas layanan.

7. Visi bisnis jangka pendek

Visi jangka pendek seperti orientasi pencapaian target penjualan dan laba tahunan, penghematan biaya, peningkatan produktifitas tahunan dapat merusak kualitas layanan yang sedang dibentuk untuk jangka panjang.

Penelitian yang dilakukan oleh Nurrahmi Hayani

(2015) yang berjudul: Analisis Tingkat Kualitas Pelayanan Pendidikan Mahasiswa Luar Negeri Suska Riau. Penelitian ini bertujuan untuk mengetahui tingkat mutu pelayanan pendidikan mahasiswa luar negeri di UIN SUSKA Riau pada tahun 2013. Subjek penelitian ini adalah mahasiswa UIN SUSKA Riau yang berasal dari luar negeri. Objek dari penelitian ini adalah tingkat kualitas pelayanan pendidikan Universitas Islam Negeri SUSKA Riau. Populasi yang diambil dalam penelitian ini adalah seluruh mahasiswa UIN SUSKA Riau yang berasal dari luar negeri terhitung sejak tahun 2008 hingga 2013. Sebanyak 144 angket telah disebarkan kepada responden yang dipilih melalui teknik proportional random sampling. Penafsiran hasil analisa dan pengolahan data mengacu kepada ketentuan dalam metode Educational Service Quality ESQ yang dikembangkan Holdford and Patkar (2003) yang dikombinasikan dengan Surat Keputusan Menteri Pendayagunaan Aparatur Negara Nomor 25/M.PAN/2/2004. Data yang terkumpul dianalisis dengan menggunakan teknik SERVQUAL dengan bantuan perangkat sofware komputer SPSS versi 17 . Hasil penelitian ini menunjukkan bahwa UIN SUSKA Riau telah mampu memberikan pelayanan pendidikan dengan tingkat mutu "B" atau Baik terhadap mahasiwa yang berasal dari luar negeri.

Khulasotul Wafiyah (2018) dengan judul penelitian: Kualitas Pelayanan Satu Pintu di Dinas Pendidikan Kota Surabaya. Penelitian ini bertujuan untuk menjelaskan pelaksaan Pelayanan Satu Pintu Dinas Pendidikan kota Surabaya, kualitas pelayanan satu pintu beserta faktor pendukung dan penghambatnya. Penelitian ini merupakan penelitian kualitatif deskriptif. Dalam proses pencarian data, penelitian menggunakan metode observasi, wawancara mendalam terhadap subyek penelitian, dan dokumentasi. Dalam analisis dan interpretasi data, peneliti menggunakan model Miles and Huberman yaitu reduksi, penyajian, dan pengambilan kesimpulan data. Sedangkan dalam uji keabsahan data peneliti menggunakan trianggulasi sumber. Hasil wawancara ini menunjukkan bahwa kualitas pelayanan satu pintu dinas pendidikan kota Surabaya sudah diterapkan dimensi Tangible, Reliability, Responsiviness, Assurance, dan Empathy beserta indikatornya. Namun ada beberapa indikator yang belum berjalan sesuai dengan keinginan masyarakat, antara lain kurangnya keamanan tempat dinas pendidikan kota Surabaya dan sarana dan prasarana yang masih belum lengkap. Faktor penghambat pelaksanaan pelayanan satu pintu dinas pendidikan kota Surabaya adalah ketidakhadiran pejabat di kantor atau sedang tugas di luar instansi dan koneksi jaringan internet yang terganggu. Sedangkan faktor pendukungnya adalah kesadaran para pegawai melayani masyarakat, pengetahuan dan pengalaman pegawai dalam melakukan tugas, jumlah pegawai yang memadai dan kelengkapan sarana dan prasarana sebagai penunjang pelayanan satu pintu.

Penelitian yang dilakukan oleh Anik (2011) dengan judul "Pengaruh Kualitas Layanan Lembaga Pendidikan terhadap Kepuasan Konsumen", penelitian ini bertujuan untuk (1) mengetahui adanya pengaruh positif antara dimensi kualitas layanan terhadap kepuasan konsumen Lembaga Pendidikan Mental Aritmetika di Kota Malang, (2) mengetahui tingkat kepuasan konsumen terhadap kinerja Lembaga Pendidikan Mental Aritmetika di Kota Malang. Penelitian ini dilakukan di Kota Malang dengan memilih enam Lembaga Pendidikan Mental Aritmetika yang menyelenggarakan program pendidikan mental aritmetika mulai tingkat dasar, tingkat lanjutan sampai tingkat mahir yang telah terdaftar pada Departemen Pendidikan Nasional Kota Malang. Besarnya sampel setiap lembaga ditetapkan secara proportional random sampling, yaitu dipilih secara acak dengan jumlah sebanding dengan jumlah peserta program pendidikan di setiap lembaga. Data dalam penelitian ini dianalisis dengan menggunakan Analisis Regresi Berganda dan Analisis Kepuasan Pelanggan. Hasil temuan dalam penelitian ini menyimpulkan bahwa secara parsial dan simultan dimensi kualitas layanan jasa (keandalan, bukti langsung, daya tanggap, jaminan dan empati) yang diberikan oleh Lembaga Pendidikan Mental Aritmetika di Kota Malang berpengaruh positif dan signifikan. Penelitian ini juga menghasilkan temuan bahwa Lembaga Pendidikan Mental Aritmetika di Kota Malang belum sepenuhnya memuaskan konsumen, karena nilai harapan konsumen masih lebih tinggi dibandingkan dengan kinerja yang ditunjukkan oleh lembaga-lembaga tersebut. Kualitas pelayanan adalah program atau strategi yang digunakan oleh Sekretariat Panitia Pelatihan Dasar CPNS Kabupaten Tebo untuk memberikan pelayanan yang lebih baik dan terpuaskan kepada peserta Pelatihan Dasar CPNS. Hal ini maksudkan untuk memberikan kepuasan kepada peserta Latsar berkaitan dengan 
pemberian pelayanan yang diberikan oleh Sekretariat Panitia Pelatihan Dasar CPNS Kabupaten Tebo.

\section{Metode}

Metode yang digunakan dalam penelitian ini adalah metode kuantitatif. Menurut Sugiyono (2016) metode kuantitatif yaitu data yang digunakan untuk meneliti pada populasi atau sampel tertentu, pengumpulan data menggunakan instrumen penelitian, analisis data bersifat kuantitatif/statistik dengan tujuan untuk menguji hipotesis yang telah ditetapkan. Jenis data yang dipergunakan dalam penelitian ini adalah data primer yaitu data yang diambil oleh peneliti langsung dari sumbernya atau responden (Sutja, dkk, 2017). Data primer dalam penelitian ini secara khusus dikumpulkan oleh peneliti dan berhubungan langsung dengan masalah yang diteliti. Data primer dalam penelitian ini diperoleh melalui penyebaran kuisioner secara langsung kepada responden yaitu Peserta Latsar CPNS Kabupaten Tebo. Pengukuran variabel merupakan tahap awal dalam sebuah pengukuran penelitian. Tujuan pengukuran variabel ini baru pada tahap menjawab pertanyaan "bagaimana cara untuk mengukur variabel tersebut". Dalam penelitian ini pengukuran yang digunakan menggunakan pengukuran skala rating (rating scale) dan skala yang digunakan adalah skala Likert.

Menurut Sugiyono (2016) skala likert digunakan untuk mengukur sikap, pendapat dan persepsi seseorang atau sekelompok orang tentang fenomena sosial. Dengan skala likert, maka variabel yang akan diukur dijabarkan menjadi indikator varianel. Dalam penelitian ini digunakan pernyataan dengan rentang skala penilaian sebagai berikut: Sangat tidak setuju $=$ nilai 1 ; Tidak setuju $=$ nilai $2 ;$ Netral $/$ Ragu - Ragu $=$ nilai $3 ;$ Setuju $=$ nilai 4; Sangat setuju $=$ nilai 5. Populasi merupakan lingkup, wilayah atau tempat keberadaan dari karakteristik subjek yang diteliti dan yang akan disimpulkan nantinya (Sutja, dkk, 2017). Populasi yang digunakan dalam penelitian ini adalah seluruh Peserta Latsar CPNS Kabupaten Tebo tahun 2019. Sampel adalah wakil representatif yang terpilih dari populasi untuk dijadikan sumber data atau responden (Sutja, dkk, 2017). Sampel dalam penelitian ini adalah Peserta Latsar Kabupaten Tebo Tahun 2019. Besarnya sampel dengan menggunakan metode pengambilan sampel menurut pendapatan Slovin (Sutja, dkk, 2017) dengan rumus sebagai berikut:

$\mathrm{n}=\frac{N}{1+N \theta^{2}}$

Dimana: $\mathrm{n}=$ Jumlah sampel representatif yang diperlukan; $\mathrm{N}=$ Jumlah populasi secara keseluruhan; $\mathrm{e}=$ Tingkat signifikansi (error) yang ditetapkan peneliti

Dengan menggunakan formula diatas dapat dihitung jumlah sampel sebagai berikut:

$\mathrm{n}=\frac{154}{1+154(0.1)^{2}}=58.33$

Jadi, jumlah sampel dibulatkan menjadi 59 orang peserta

Teknik sampling adalah teknik pengambilan sampel (Sugiyono, 2016,56) Adapun teknik pengambilan sampel, dengan menggunakan teknik proportionate stratified random sampling. Proportionate Stratified Random Sampling biasa digunakan pada populasi yang mempunyai susunan bertingkat atau berlapis-lapis. Teknik ini digunakan bila populasi mempunyai anggota/unsur yang tidak homogen dan berstrata secara proporsional. Dalam stratified random sampling elemen populasi dikelompokkan pada tingkatan-tingkatan tertentu dengan tujuan pengambilan sampel akan merata pada seluruh tingkatan dan sampel mewakili karakter seluruh elemen populasi yang heterogen. Alasan menggunakan teknik ini karena yang menjadi populasi dalam penelitian ini hanya Peserta Latsar CPNS Kabupaten Tebo yang terbagi berdasarkan Golongan yaitu Golongan II dan Golongan III, juga berdasarkan Jenis Kelamin yaitu Laki-Laki dan Perempuan. Agar semua dapat terwakili, maka sampel diambil dari masing-masing kelas dengan proporsi yang sama.

Tabel 3

Daftar Sampel Penelitian berdasarkan Golongan

\begin{tabular}{|l|l|c|c|c|}
\hline No & \multicolumn{1}{|c|}{ Golongan } & Jumlah Peserta & Persentase & Sampel \\
\hline 1 & Golongan II & 40 & $30 \%$ & 12 \\
\hline 2 & Golongan III & 114 & $30 \%$ & 35 \\
\hline & Jumlah & $\mathbf{1 5 4}$ & & $\mathbf{4 7}$ \\
\hline
\end{tabular}

Sumber : Data Primer (diolah) Tahun 2020

Tabel 4

Daftar Sampel Penelitian berdasarkan Jenis Kelamin

\begin{tabular}{|c|l|c|c|c|}
\hline No & \multicolumn{1}{|c|}{ Jenis Kelamin } & Jumlah Peserta & Persentase & Sampel \\
\hline 1 & Laki-Laki & 106 & $30 \%$ & 32 \\
\hline 2 & Perempuan & 48 & $30 \%$ & 15 \\
\hline & Jumlah & $\mathbf{1 5 4}$ & & $\mathbf{4 7}$ \\
\hline
\end{tabular}

Sumber : Data olahan 
Untuk keperluan tersebut peneliti menggunakan teori Umar (2013) mengatakan bahwa skor setiap komponen yang diteliti dengan mengalikan seluruh frekuensi dan nilai bobot dengan rumus sebagai berikut: Skor terendah $=$ bobot terendah $\mathrm{x}$ jumlah sampel Skor tertinggi $=$ bobot tertinggi $\mathrm{x}$ jumlah sampel Skor terendah $=1 \times 59=59$

Skor terendah $=5 \times 59=295$
Sedangkan untuk mencari rentang skala menurut Rangkuti (2011) digunakan rumus sebagai berikut: $R_{s}=\frac{n(m-1)}{m}=5$

Jadi setelah diperoleh besarnya rentang skala, maka rentang skala kriteria penilaian tersebut dapat diurutkan sebagai berikut:

Tabel 5

Rentang Skor Skala Variabel Kualitas Pelayanan dan Kepuasan Peserta Latsar CPNS Kabupaten Tebo

\begin{tabular}{|c|c|c|}
\hline Variabel & Rentang Penelitian & Kategori \\
\hline \multirow{4}{*}{ Kualitas pelayanan } & $59-106,1$ & Sangat Rendah \\
\cline { 2 - 3 } & $106,2-153,3$ & Rendah \\
\cline { 2 - 3 } & $153,4-200,5$ & Sedang \\
\cline { 2 - 3 } & $200,6-247,7$ & Tinggi \\
\cline { 2 - 3 } & $247,8-295$ & Sangat Tinggi \\
\hline \multirow{5}{*}{ Kepuasan peserta } & $59-106,1$ & Sangat Rendah \\
\cline { 2 - 3 } & $106,2-153,3$ & Rendah \\
\cline { 2 - 3 } & $153,4-200,5$ & Sedang \\
\cline { 2 - 3 } & $200,6-247,7$ & Tinggi \\
\cline { 2 - 3 } & $247,8-295$ & Sangat Tinggi \\
\hline
\end{tabular}

Sumber : Data olahan

Data dalam penelitian ini dianalisis dengan menggunakan analisis regresi sederhana. Analisis regresi sederhana digunakan untuk melihat pengaruh dimensi kualitas pelayanan terhadap kepuasan Peserta Latsar Kabupaten Tebo. Analisis regresi sederhana dengan model berikut:

$\mathrm{Y}=\mathrm{a}+\mathrm{bx}+\mathrm{e}$

Keterangan: $\mathrm{Y}=$ kepuasan Peserta; $\mathrm{a}=$ konstanta; $\mathrm{x}=$ kualitas pelayanan; $\mathrm{e}=$ standard error

\section{Uji Hipotesis}

Uji $t$

Uji $\mathrm{t}$ digunakan untuk menguji signifikan pengaruh Kualitas Pelayanan terhadap kepuasan mahasiswa $(\mathrm{Y})$ secara individual.

1) H1 diterima berarti terdapat pengaruh yang positif antara variabel independen terhadap variabel dependen

2) Menentukan tingkat signifikan $(\alpha)$ sebesar 0,05 membandingkan $t_{\text {hitung }}$ dengan $t_{\text {tabel }}$, jika $t_{\text {hitung }}$ lebih besar dari $t_{\text {tabel }}$ maka $\mathrm{H} 1$ diterima.

3) Berdasarkan probabilitas $\mathrm{H} 1$ akan diterima jika nilai probabilitasnya kurang dari $0,05(\alpha)$

4) Menentukan variabel independen nama yang mempunyai pengaruh paling dominan terhadap variabel dependen, hubungan ini dapat dilihat dari koefisien regresinya.

\section{Koefisien Determinasi $\left(R^{2}\right)$}

Koefisien determinasi $\left(\mathrm{R}^{2}\right)$ pada intinya mengukur seberapa jauh model dalam menerangkan variabel dependen. Nilai $\mathrm{R}$ square yang kecil berarti kemampuan variabel-variabel independen dalam menjelaskan variabel dependen. Sebaliknya, nilai $\mathrm{R}$ square yang mendekati satu menandakan variabelvariabel independen memberikan hampir semua informasi yang dibutuhkan oleh variabel dependen. $\mathrm{R}^{2}=$ 0 , maka tidak ada sedikitpun persentase sumbangan pengaruh yang diberikan variabel bebas terhadap variabel tergantung, atau variasi variabel bebas yang digunakan dalam model tidak menjelaskan sedikitpun variasi variabel tergantung. Sebaliknya $R^{2}=1$, maka persentase sumbangan pengaruh yang diberikan variabel bebas terhadap variabel tergantung adalah sempurna, atau variasi variabel bebas yang digunakan dalam model menjelaskan $100 \%$ variasi variabel tergantung koefisien determinan bila diakarkan $(\sqrt{ })$ menjadi koefisien korelasi (R) dan bila dikuadratkan menjadi koefisien determinasi $\left(\mathrm{R}^{2}\right)$.

\section{Hasil}


Tabel 6

Hasil Uji Regresi Linier Sederhana (I)

\section{Golongan II}

\begin{tabular}{|l|l|r|r|r|}
\hline \multicolumn{2}{|c|}{ Model } & \multicolumn{2}{|c|}{ Unstandardized Coefficients } & \multicolumn{2}{|c|}{ t } & \multicolumn{1}{c|}{ Sig. } \\
\cline { 3 - 5 } 1 & Std. Error & 4.087 & -1.933 & .082 \\
\cline { 2 - 5 } & X & .184 & 7.059 & .000 \\
\hline
\end{tabular}

Sumber: Data primer (diolah), 2020

Berdasarkan hasil analisis regresi linier sederhana didapatkan persamaan regresi sebagai berikut: $\mathrm{Y}=4,087+0,184 \mathrm{X}$

Persamaan garis regresi itu dapat dijelaskan sebagai berikut:

1. Nilai konstanta (intercept) sebesar 4.087 memberikan arti bahwa apabila Kualitas Pelayanan diasumsikan $=0$ maka kepuasan Peserta secara konstan bernilai 4.087 .

2. Koefisien regresi Kualitas Pelayanan berpengaruh positif terhadap kepuasan Peserta Latsar CPNS Kab. Tebo. Hal ini menunjukkan bahwa dengan penambahan satu-satuan Kualitas Pelayanan, maka akan terjadi peningkatan kepuasan peserta sebesar 0,184

Tabel 7

Hasil Uji Regresi Linier Sederhana (II)

Golongan III

\begin{tabular}{|l|l|r|r|r|}
\hline \multicolumn{2}{|l|}{ Model } & \multicolumn{2}{|c|}{ Unstandardized Coefficients } & \multicolumn{2}{|c|}{ Sig. } \\
\cline { 3 - 4 } 1 & Std. Error & $\mathrm{t}$ & .981 \\
\cline { 3 - 6 } & X Constant) & 4.042 & .024 & .000 \\
\hline
\end{tabular}

Sumber: Data primer (diolah), 2020

Berdasarkan hasil analisis regresi linier sederhana didapatkan persamaan regresi sebagai berikut: $\mathrm{Y}=4.042+0,187 \mathrm{X}$

Persamaan garis regresi itu dapat dijelaskan sebagai berikut:

1. Nilai konstanta (intercept) sebesar 4.042 memberikan arti bahwa apabila Kualitas Pelayanan diasumsikan $=0$ maka kepuasan Peserta secara konstan bernilai 4.042

2. Koefisien regresi Kualitas Pelayanan berpengaruh positif terhadap kepuasan Peserta Latsar CPNS Kab. Tebo. Hal ini menunjukkan bahwa dengan penambahan satu-satuan Kualitas Pelayanan, maka akan terjadi peningkatan kepuasan peserta sebesar 0,187

Tabel 8

Hasil Uji Regresi Linier Sederhana (III)

Jenis Kelamin Laki-Laki

\begin{tabular}{|c|c|c|c|c|}
\hline \multirow{2}{*}{\multicolumn{2}{|c|}{ Model }} & Unstandardized Coefficients & \multirow[b]{2}{*}{$\mathrm{T}$} & \multirow[b]{2}{*}{ Sig. } \\
\hline & & Std. Error & & \\
\hline \multirow[t]{2}{*}{1} & (Constant) & 3.207 & .225 & .824 \\
\hline & $\mathrm{X}$ & .145 & 6.477 & .000 \\
\hline
\end{tabular}

Sumber: Data primer (diolah), 2020

Berdasarkan hasil analisis regresi linier sederhana didapatkan persamaan regresi sebagai berikut: $\mathrm{Y}=3.207+0,145 \mathrm{X}$

Persamaan garis regresi itu dapat dijelaskan sebagai berikut:
1. Nilai konstanta (intercept) sebesar 3.207 memberikan arti bahwa apabila Kualitas Pelayanan diasumsikan $=0$ maka kepuasan Peserta secara konstan bernilai 3.207 
Musfarita Affiani, Pengaruh Kualitas Pelayanan pada Kepuasan Peserta Pelatihan Dasar CPNS Kabupaten Tebo Provinsi Jambi

2. Koefisien regresi Kualitas Pelayanan berpengaruh positif terhadap kepuasan Peserta Latsar CPNS Kab. Tebo. Hal ini menunjukkan bahwa dengan penambahan satu-satuan Kualitas Pelayanan, maka akan terjadi peningkatan kepuasan peserta sebesar 0,145

Tabel 9

Hasil Uji Regresi Linier Sederhana (III)

Jenis Kelamin Perempuan

\begin{tabular}{|c|c|c|c|c|}
\hline \multirow{2}{*}{\multicolumn{2}{|c|}{ Model }} & Unstandardized Coefficients & \multirow[b]{2}{*}{$\mathrm{t}$} & \multirow[b]{2}{*}{ Sig. } \\
\hline & & Std. Error & & \\
\hline \multirow[t]{2}{*}{1} & (Constant) & 4.574 & -1.768 & .100 \\
\hline & $\mathrm{X}$ & .208 & 6.380 & .000 \\
\hline
\end{tabular}

Sumber: Data primer (diolah), 2020

Berdasarkan hasil analisis regresi linier sederhana didapatkan persamaan regresi sebagai berikut:

$\mathrm{Y}=4.574+0,208 \mathrm{X}$

Persamaan garis regresi itu dapat dijelaskan sebagai berikut:

1. Nilai konstanta (intercept) sebesar 4.574 memberikan arti bahwa apabila Kualitas Pelayanan diasumsikan $=0$ maka kepuasan Peserta secara konstan bernilai 4.574

2. Koefisien regresi Kualitas Pelayanan berpengaruh positif terhadap kepuasan Peserta Latsar CPNS
Kab. Tebo. Hal ini menunjukkan bahwa dengan penambahan satu-satuan Kualitas Pelayanan, maka akan terjadi peningkatan kepuasan peserta sebesar 0,208

\section{Uji Hipotesis}

Untuk melihat pengaruh Kualitas Pelayanan secara parsial terhadap kepuasan Peserta Latsar CPNS Kab. Tebo dapat dilihat pada tabel 4.8 berikut ini:

Tabel 10

Perbandingan $t$ Hitung dan $t$ Tabel

\begin{tabular}{|l|r|r|r|r|}
\hline \multicolumn{1}{|c|}{ Uji t Satu Arah } & \multicolumn{1}{|c|}{ Gol 2 } & \multicolumn{1}{c|}{ Gol 3 } & \multicolumn{1}{c|}{ Laki-laki } & \multicolumn{1}{c|}{ Perempuan } \\
\hline $\mathrm{t}$ Hitung & 7,059 & 5,287 & 6,477 & 6,380 \\
\hline $\mathrm{t}$ Tabel & 2,22814 & 2,03452 & 2,04227 & 2,16037 \\
\hline
\end{tabular}

Sumber: Data primer (diolah), 2020

a. Golongan II

\begin{tabular}{|l|l|}
\hline Taraf Signifikansi & $5 \%$ atau 0,05 dan Nilai Df = N-K-I = 12-1-1 = 10 maka didapat nilai t Tabel = 2,22814 \\
\hline Kesimpulan & $\begin{array}{l}\text { t Hitung > t Tabel yaitu 7,059 > 2,22814 artinya artinya Kualitas Pelayanan berpengaruh } \\
\text { positif Terhadap Kepuasan Peserta Latsar CPNS Golongan II Kab. Tebo }\end{array}$ \\
\hline
\end{tabular}

\section{b. Golongan III}

Taraf Signifikansi

Kesimpulan
$5 \%$ atau 0,05 dan Nilai $\mathrm{Df}=\mathbf{N}-\mathbf{K}-\mathbf{1}=\mathbf{3 5 - 1 - 1}=\mathbf{3 3}$ maka didapat nilai $\mathrm{t}$ Tabel $=2,03452$ t Hitung > t Tabel yaitu 5,287 > 2,03452 artinya artinya Kualitas Pelayanan berpengaruh positif Terhadap Kepuasan Pelanggan Pegawai Gol. 3

\section{c. Jenis Kelamin Laki-Laki}

Taraf Signifikansi $5 \%$ atau 0,05 dan Nilai $\mathrm{Df}=\mathbf{N}-\mathbf{K}-\mathbf{1}=\mathbf{3 2 - 1 - 1}=\mathbf{3 0}$ maka didapat nilai $\mathrm{t}$ Tabel $=2,04227$

Kesimpulan t Hitung > t Tabel yaitu 6,477> 2,04227 artinya artinya Kualitas Pelayanan berpengaruh positif Terhadap Kepuasan Peserta Latsar CPNS Laki-laki Kabupaten Tebo

\section{d. Jenis Kelamin Perempuan}

Taraf Signifikansi $5 \%$ atau 0,05 dan Nilai $\mathrm{Df}=\mathbf{N}-\mathbf{K}-\mathbf{1}=\mathbf{1 5 - 1 - 1}=\mathbf{1 3}$ maka didapat nilai $\mathrm{t}$ Tabel $=2,16037$

Kesimpulan $\mathrm{t}$ Hitung > t Tabel yaitu 6,380 > 2,16037 artinya artinya Kualitas Pelayanan berpengaruh positif Terhadap Kepuasan Peserta Latsar CPNS Perempuan Kabupaten Tebo 
Tabel 11

Hasil Koefisien Determinasi (I)

a. Golongan II

\begin{tabular}{|l|r|r|r|rr|}
\hline Model & R & R Square & Adjusted R Square & Std. Error of the Estimate \\
\hline 1 & $.913^{\mathrm{a}}$ & .833 & .816 & 1.27765 \\
\hline
\end{tabular}

Sumber: Data primer (diolah), 2020

Berdasarkan tabel diatas diperoleh besarnya koefisien determinasi ( $\mathrm{R}$ square) 0,833. Artinya bahwa sebesar 83,3\% variasi kepuasan peserta Latsar Golongan
II (Y) dijelaskan oleh variabel Kualitas Pelayanan sedangkan sisanya sebesar $16,7 \%$ dijelaskan oleh variabel lain yang tidak terdapat dalam model.

Tabel 12

Hasil Koefisien Determinasi (II)

\section{b. Golongan III}

\begin{tabular}{|l|r|r|l|lr|}
\hline Model & R & R Square & Adjusted R Square & Std. Error of the Estimate \\
\hline 1 & $.677^{\mathrm{a}}$ & .459 & .442 & 1.5696 \\
\hline
\end{tabular}

Sumber: Data primer (diolah), 2020

Berdasarkan tabel diatas diperoleh besarnya koefisien determinasi (R square) 0,459. Artinya bahwa sebesar 45,9\% variasi kepuasan peserta Latsar Golongan
III (Y) dijelaskan oleh variabel Kualitas Pelayanan sedangkan sisanya sebesar $54,1 \%$ dijelaskan oleh variabel lain yang tidak terdapat dalam model.

Tabel 13

Hasil Koefisien Determinasi (III)

\section{c. Jenis Kelamin Laki-Laki}

\begin{tabular}{|l|r|r|r|rr|}
\hline Model & R & R Square & Adjusted R Square & Std. Error of the Estimate \\
\hline 1 & .591 & .577 & 1.48069 & .591 \\
\hline
\end{tabular}

Sumber: Data primer (diolah), 2020

Berdasarkan tabel diatas diperoleh besarnya koefisien determinasi ( $\mathrm{R}$ square) 0,577. Artinya bahwa sebesar 57,7\% variasi kepuasan peserta Latsar Laki-Laki
(Y) dijelaskan oleh variabel Kualitas Pelayanan sedangkan sisanya sebesar $42,3 \%$ dijelaskan oleh variabel lain yang tidak terdapat dalam model.

Tabel 14

Hasil Koefisien Determinasi (IV)

\section{d. Jenis Kelamin Perempuan}

\begin{tabular}{|l|r|r|r|rr|}
\hline Model & R & R Square & Adjusted R Square & Std. Error of the Estimate \\
\hline 1 & $.871^{\mathrm{a}}$ & .758 & .739 & 1.41803 \\
\hline
\end{tabular}

Sumber: Data primer (diolah), 2020

Berdasarkan tabel diatas diperoleh besarnya koefisien determinasi ( $\mathrm{R}$ square) 0,739. Artinya bahwa sebesar $73,9 \%$ variasi kepuasan peserta Latsar Perempuan (Y) dijelaskan oleh variabel Kualitas Pelayanan sedangkan sisanya sebesar $26,1 \%$ dijelaskan oleh variabel lain yang tidak terdapat dalam model. Berdasarkan hasil analisis diketahui bahwa variabel Kualitas Pelayanan (X) secara parsial berpengaruh positif dan signifikan terhadap kepuasan Peserta Latsar CPNS Kabupaten Tebo. Kualitas Pelayanan yang diberikan oleh BKPSDMD Kabupaten Tebo. Dari indikator-indikator tersebut selanjutnya akan digunakan oleh pihak BKPSDMD Kabupaten Tebo untuk mempertahankan Kualitas Pelayanan yang telah ada serta meningkatkannya bila diperlukan, seperti perbaikan dan peningkatan kebersihan kamar, ruang belajar dan kamar mandi. Perbaikan yang dilakukan sebagai bukti bahwa BKPSDMD Kabupaten Tebo berusaha memberikan layanan yang terbaik guna meningkatkan kepuasan Peserta. Pihak manajemen harus memikirkan hal semacam ini, agar konsumen mendapatkan kemudahan-kemudahan, tentunya semacam ini tidak akan didapat tanpa adanya perencanaan yang matang dan kekompakan-kekompakan semua pihak yang ada pada BKPSDMD.

Kabupaten Tebo. Menurut Parasuraman dalam Tjiptono (2004) mendefinisikan reliability mencakup dua hal pokok, yaitu konsistensi kerja (performance) dan kemampuan untuk dipercaya (dependability). Dengan demikian dapat dikatakan bahwa yang turut 
mempengaruhi kepuasan peserta BKPSDMD Kabupaten Tebo adalah kualitas layanan yang ditunjukkan dengan memberikan kemudahan-kemudahan bagi konsumen dan keakuratan dalam menangani keluhan para peserta tersebut. Kesimpulannya adalah bahwa tingkat kepuasan peserta Latsar dipengaruhi oleh terpenuhi tidaknya harapan peserta pada keandalan, yaitu keakurasian, ketepatan dan ketangkasan panitia dalam pelayanan dan widyaiswara terhadap peserta. BKPSDMD Kabupaten Tebo memberikan informasi yang jelas dan mudah dimengerti serta kecepatan menangani keluhan peserta. Panitia dan Widyaiswara memegang peranan penting dalam memberikan kualitas layanan yang mampu memberikan kepuasan bagi peserta, karena peserta memiliki kemampuan berfikir matematis yang berbedabeda, maka widyiswara harus memiliki daya tanggap yang baik terutama dalam pemberian informasi pada proses pembelajaran dan ketepatan menyelesaikan masalah, sehingga membuat peserta merasa lebih nyaman dan puas. Kualitas layanan oleh BKPSDMD Kabupaten Tebo merujuk pada keramahan dan kesopanan panitia dalam memberikan layanan, penanganan keluhan dan berlaku adil dalam memberikan sanksi kepada peserta.

Berdasarkan hasil uji $F$ diketahui bahwa Kualitas Pelayanan secara simultan berpengaruh signifikan terhadap kepuasan peserta Latsar CPNS Kabupaten Tebo. Dalam upaya peningkatan kualitas pelayanan pihak BKPSDMD Kabupaten Tebo senantiasa harus selalu meningkatkan kualitas pelayanan yang diberikannya. Hal ini dilakukan dengan selalu berusaha untuk memperbaiki bukti fisik, keandalan, daya tanggap, empati dan jaminan. Dengan adanya pembenahan dalam dimensi-dimensi pelayanan tersebut diharapkan dapat mempertahankan kepuasan peserta Latsar CPNS Kabupaten Tebo. Dengan tercapainya kepuasan konsumen dapat memberikan beberapa manfaat, yaitu hubungan antara BKPSDMD dengan peserta menjadi harmonis, memberikan dasar yang baik bagi para peserta Latsar CPNS dan akan memberikan cerita positif dari mulut ke mulut. Dengan terciptanya kepuasan peserta tersebut sangat membantu BKPSDMD Kabupaten Tebo untuk meningkatkan kinerja Layanan agar selalu berubah menjadi lebih baik.

\section{Simpulan}

BKPSDMD Kabupaten Tebo diharapkan dapat mempertahankan pelayanan yang diberikan sehingga dapat menjaga kepuasan Peserta Latsar CPNS Kabupaten Tebo yang akan datang.

\section{Daftar Pustaka}

Anik Indrawati. (2011). Pengaruh Kualitas Layanan Lembaga Pendidikan terhadap Kepuasan Konsumen. Jurnal Ekonomi Bisnis, TH. 16, No. 1.
Kotler, Philip \& Keller, KL.. (2003). Manajemen Pemasaran: Edisi Kesepuluh. Diterjemahkan oleh: Bob Sabran. Jakarta: PT. Indeks.

Kotler, Philip \& Keller, KL. (2009). Manajemen Pemasaran: Edisi ke-13. Diterjemahkan oleh: Bob Sabran. Jakarta: Erlangga.

Khulasotul, Wafiyah. (2018). Kualitas Pelayanan Satu Pintu di Dinas Pendidikan Kota Surabaya. Skripsi. Surabaya: UIN Sunan Ampel.

Hayani, Nurrahmi. (2015). Analisis Tingkat Kualitas Pelayanan Pendidikan Mahasiswa Luar Negeri di Universitas Islam Negeri Suska Riau. Kutubkhanah, Volume 18 Nomor 1.

Nurrahmi, Hayani. (2015). Analisis Tingkat Kualitas Pelayanan Pendidikan Mahasiswa Luar Negeri Suska Riau. Khutubkhanah, Volume 18 Nomor 1.

Rangkuti, Freddy. (2011). Measuring Customer Satisfaction. Jakarta: Gramedia Pustaka Utama.

Sekaran, Uma. (2006). Metodologi Penelitian Untuk Bisnis. Jakarta: Salemba Empat.

Siregar, Syofian. (2010). Statistika Deskriptif untuk Penelitian. Jakarta: Rajawali Pers.

Sugiyono. (2016). Metode Penelitian: Kuantitatif, Kualitatif, dan $R \& D$. Bandung: Alfabeta.

Sutja, Akmal; dkk. (2017). Penulisan Skripsi untuk Produi Bimbingan Konseling. Yogyakarta: Wahana Resolusi.

Tjiptono, Fandy; dkk.. (2008). Pemasaran Strategik. Yogyakarta: ANDI.

Tjiptono, F., \& Chandra, G. (2011). Service Quality \& Satisfaction. Yogyakarta: ANDI. 